\title{
A STUDY OF FOREIGN DIRECT INVESTMENT ON MANUFACTURING INDUSTRIES IN SULTANATE OF OMAN
}

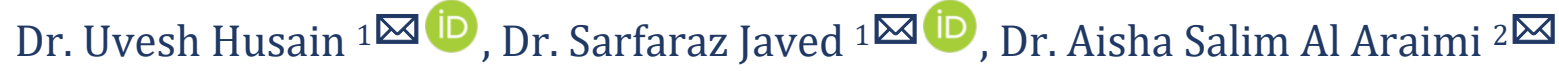 \\ 1,2,3 Economics and Business Studies Department, Mazoon College, Muscat, Oman
}

DOI: https://doi.org/10.29121/granthaalayah.v9.i3.2021.3696

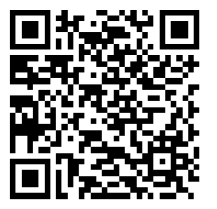

Article Type: Research Article

Article Citation: Dr. Uvesh Husain, Dr. Sarfaraz Javed, and Dr. Aisha Salim Al Araimi. (2021). A STUDY OF FOREIGN DIRECT INVESTMENT ON MANUFACTURING INDUSTRIES IN SULTANATE OF OMAN. International Journal of Research GRANTHAALAYAH, 9(3), 1-9. https://doi.org/10.29121/granthaa layah.v9.i3.2021.3696

Received Date: 12 February 2021

Accepted Date: 18 March 2021

Keywords:

FDI

Manufacturing Companies

Spillover

Economic Growth and Oman

\begin{abstract}
The objective of this research is to find impact of foreign direct investment on manufacturing industries in Oman. The study utilized a quantitative research method which applied primary and secondary data obtained from Oman's World Bank database (1984-2018). The primary data were collected from a research questionnaire administered to 410 respondents from nine industrial sectors, namely: Textile, Petroleum goods, Electronics, Automotive, Food \& Beverages, Agriculture \& Fishery, Publishing, Chemicals and Pharmaceutics. The results of this study also revealed that the spillover impacts on domestic companies, like novel technology, marketing strategies, organizational skills, money, jobs, export growth, diversifying of economy and greater competition, lead to enhanced domestic market efficiency and boosted productivity in skill-spreading host economies with the highest impact accompanied with Capital and Technology spillover.
\end{abstract}

\section{INTRODUCTION}

Foreign Direct Investment (FDI) is termed as an investment dedicated for procuring a long-lasting returns in a trade carrying out it's in an economy that is different from an investment firm, the motive behind this is to get a longlasting returns and having an efficient marshal the management of the business. As pointed out by Hill (2005:13), FDI may be viewed as a long-lasting investment by an international industrialist into a business situated in a location away from his/her home country. In the 1990s, FDI developed as the major source of foreign funding for developed countries. In 1997, FDI funded about 50 percent of all private investment and its domestic capital flows to developing countries was estimated at 40\% (Aitken and Harrison, 1999). After the declining of commercial bank lending in the 1980 s, policy strategists in developing countries lessened checks on inbound foreign investment. Several nations also shifted the balance by making available specific incentives such as reduction on taxes or income tax, exemption from import duties, and subsidizes on social amenities to entice foreign companies (Aitken and Harrison, 1999). The logic behind these preferential privileges stems from an impression that foreign investment generates external costs when technology is transferred. 
Advanced management experience from international companies provides competitive skills to local businesses. The client, as the outcome manufacturer for the related inputs, then functions either inside or at the boundary. The initial outcome is extremely inefficient while the latter reflects some degree of technological efficacy. Through analyzing the actions of MNCs, domestic companies can determine how more results can be produced by the predefined integration of inputs, or whether they can manufacture at a certain level of output with fewer integrated inputs. This production feature is known as the capacity to steer clear waste or slackness by producing result commensurate to the input (Kravtsova and Zelenyuk, 2007). Additionally, experience in cost-effectiveness is a crucial element for scale performance. Regional businesses are studying how to reach the optimal productivity scale, given some of the tools available. Many firms can operate below a variable return to scale, so learning about the actions of international firms will substantially improve their return to scale or increase their productivity (Girma and Görg 2007).

Consequently, gains in efficiency from inbound FDI can be transferred to two specific media: spillovers in intraindustry performance and spillovers in inter-industry efficiency (Lin et al. 2009; Keller 2009). Where the accessibility of international companies creates productivity in the same sector for local firms, these spillovers are viewed as horizontal spillovers. Conversely, if inbound foreign firms raise local firms' growth through various sectors, these spillovers are viewed as vertical spillovers. Horizontal spillovers may take place through three components of transmission mechanisms for spillover output. They are result of design, mobility of the labor force and competitiveness. In the meantime, vertical spillovers are harnessed into vertical intersections.

The study's focus is on identifying the true effect of FDI in making the domestic manufacturing sector more efficient and productive in oil-producing countries.

The hypotheses of this study are as follows:

Hypothesis One

$\mathrm{H}_{01}$ : There is no significant relationship between spillover of FDI and growth of domestic companies in Oman Hypothesis Two

$\mathrm{H}_{02}$ : There is no significant impact of spillover of foreign direct Investment on the economy of Oman

\section{LITERATURE REVIEW}

\subsection{CONCEPT OF FOREIGN DIRECT INVESTMENT}

Mkpakan (2004:1) considers FDI as a financial undertaking stemming from capital growth. The concept is regularly viewed as sound, since when a shareholder needs to invest in FDI, the funds will be transferred to a foreign account, capital, innovation, staff as well as company capital. In addition, the capital transaction through FDI is only a channel out of many channels through which funds can be transacted within countries. It also noted that foreign investment may be made by trading of assets, such as inventions, patents, licenses, equipment and technological capabilities, alongside equity claims without significant transfer of funds, by foreign exchange, which should be evidence of capital transaction. FDI consists of external resources like innovation, organizational, capital and professional advertisement. All of these have significant impact on the country's artistic abilities. Kumar (2007), represented FDI in various forms, may include, first, the infusion of equity capital by the parent company by the acquisition of shares in foreign partners. FDI takes place when investors located in one nation, the home nation; secure an asset in another nation with an asset management plan. FDI is defined as an investment to obtain enduring profits and to acquire a minimum of $10 \%$ of the share of equity in a company that operates within a nation apart from investors from the host country (Mwilima, 2003).

\subsection{OMAN ECONOMIC SECTOR}

In 2016, Omani Sultanate was ranked 70th among 189 economies engaged in business operations and 77th in 2015 as a result of the World Bank's 2016 ranking. Oman's port sector is supporting business in Oman and sustaining economic growth. Equally positively, it enhances the implementation of a plan to diversify the economy of the nation, as stated in Oman's 2020 vision, and reduces the nation's overwhelming dependence on oil with the price instability of its products in 2040. Oman's trading recently showed a significant growth. From 2011 to 2015, imports of goods rose from RO 9235.2 million to R0 11,153.3 million with cumulative growth of (CAGR) 5.43 percent. 
In addition, there was a decrease to R0 8900.2 million (NCSI 2017) in imports of goods during 2016. From 20112015 , the volume of re-export rose from 2247.6 million to 2571.6 million, with a CAGR of 3.42 percent. Nonetheless, the export of goods declined from R0 18,106.8 million to RO 10,295.3 million between 2011 and 2016, with a CAGR of - 10.7 percent (NCSI 2017) and a fall in oil prices. According to NCSI (2017), the majority of the estimates of Oman's commodity imports entered through seaports in 2016 and 32\% were transported via land ports.

\subsection{INDUSTRIAL ESTATES IN OMAN}

In addition to the Al Mazunah Free Zone and IT Hub called Oasis Muscat (KOM), 7 industrial metropolises are supervised and operated by the Government Establishment for Industrial Estates-Madayn. Madayn is a component of global economic system that is designed to reach out to the international world by building and maintaining sophisticated business metropolises compatible with the best perceptions of the world. Madayn's goal reinforces Oman's role as a key regional hub for development, ICT, technological innovation and its goal of facilitating business investment and continuing to promote better infrastructure, value-added services and efficient government operations through regional and global competitive policies.

Sohar-based industries

Oman spent over USD 5billion onthe steel sector, in which the country strives to become a top leading producer of the Gulf Cooperation Council. Besides steel industry, the aluminum industry also exists in the industrial region of Sohar.

Sohar Aluminium Company

Sohar Aluminum inc. was incorporated in 2004 and is viewed as top leading inventions that performed an essential part in diversifying the nation's economy. One critical goal of Sohar Aluminum's policy is to promote and strengthen development within the downstream aluminum industry Sultanate. Over the 12 phases of their manufacturing process, a new facility established in Sohar to produce alloy wheels that possess export value targeting R020mn is projected to create about 500 jobs for professional local employees. Sohar Aluminum Plant, which is situated nearby to the alloy wheel plant, will provide 45 percent of the materials needed for the expected production.

\subsection{TREND OF FDI IN OMAN}

The proportion of FDI inflows to GCC nations where Oman is, showed a decline from 1.74 percent to 1.65 percent from 2011 to 2013. In accordance with the UAE, the Sultanate of Oman has an upstanding FDI movement path from the 1990s. In 2013, FDI recorded an increase of 56 percent compared to 9.2 percent in the UAE. Also in conjunction with this nature of ventures in Oman it has greatly improved to the extent that it becomes the third place even among nations of the Middle East and North Africa (MENA) and ranked as the 47th worldwide based on the efficiency of the favorable business environment due to the World Bank classification in 2013. International investment is seen as strong to Sultanate of Oman for different reasons. In any case, it implies the long-term strategic plan of the country "Vision Oman 2020" which centers on economic diversification to curtail its considerable dependence on oil as worthwhile support of the economy. Secondly, the oil wealth of the nation is small, so FDI can supplement the economy with extra resources, which will improve the viability of the country's economy. To attract FDI, Oman has begun some restructuring focused on financing and economy policies embodied in the 'Vision Oman 2020.' The technique emphasized diversifying the economy, how regional HR can be developed, how private companies dominate economic activities and how foreign investment can be enhanced. Nevertheless, the FDI criteria and guidelines noted with various alterations in 1994 presented investors with commendable motivations.

\section{THEORIES OF INVESTMENT}

\subsection{KEYNESIAN THEORY OF INVESTMENT}

Predicated on Keynesian theory, the idea of speculation is known as investment which is applied to capital. It contributes to a rise in revenue and production through rising capital goods production and procurement. Investment also requires new equipment, road construction projects, homes, dams, etc. Robinson said, "By venture, 
A Study of Foreign Direct Investment on Manufacturing Industries in Sultanate of Oman

capital expansion is implied, for example, capital expansion. Speculation means the extension of the availability of goods in presence".

\section{TYPES OF INVESTMENT}

Instigated Investment: This is referred to as motivated revenue or profit. Elements like costs, salaries, and interest charges have effect on motivated investment. As a consequence, demand often affects it. At a time when there is an increase in revenue, demand for consumption is rising equally and investment is also increasing in order to balance this increase.

Autonomous Investment: This type of investment is revenue-independent and thus negligible. Exogenous elements like technology, innovations, growth in population and employment affect the investment. No matter how it may be, it is not influenced by variance in demand; it has a relative effect on the demand.

Keynesian Investment theory stresses the role of interest rate to investment decisions. However it may be, different components are equally present in the model. Interest rate fluctuations will affect the amount of expenditure expected by private entities of the economy. Be that as it may, a decrease in interest rates would minimize investment costs in relation to potential production; as a result capital expenditure in reach may be of benefit. There is an inverse correlation between interest rate and investment. When evaluating the effect of FDIs on economic growth, it is obvious that there may be some shortcomings in terms of what FDIs add to spillovers of information. So, under what circumstances will FDIs have positive spillover effects on the technology? According to the World Bank study on spillovers of FDIs in Sub-Saharan Africa, there are restrictions that classify into: international company characteristics, domestic company characteristics, delivery networks (supply chains, labor turnover, and industry restructuring), host country factors and institutional structures (Farole \& Winkler 2014).

Explicitly, Farole and Winkler (2014) choose an analytical method in chapters three and four of this study to assess the absorptive capacities encouraging FDI linkages, employing simple regressions to explain the effect of this variable on FDI spillovers (p. 71, 97). Having explained these important factors, it is obvious that the "absorptive institutional power" in the host community is a key factor in achieving positive externalities for the FDI in full. This aspect was highlighted in an OECD analysis evaluating the capacity of FDIs in China; adopting a simple production feature (measuring FDI as an independent variables impacting the dependent variables, output) the researchers indicated that the efficiency of FDI inflows together with the complementary resources in host regions are primary factor of knowledge-based externalities (Fu, 2008).

Researches in the MENA region also show that structural variables like property rights, are one of the significant indicators of the region's FDI inflows (Mohamed \& Sidiropoulos, 2010). In addition, according to an Economic Update Report issued by the national Bank of Kuwait (2014), the GCC region aimed to improve its business climate, significantly in relation to facilitating business factors (starting, obtaining credit, implementing contracts, etc.) to facilitate FDI inflows into the region. This further confirms the importance of this work to the complete review of institutional variables such as investment climates

Bwalya (2006) examines possible spillover effects on Zambia's companies and reveals that there is no evidence for successful spillovers in the intra-industry. In addition, its findings indicate beneficial effects at regional level. Due to access to MNE, domestic companies in the manufacturing sectors are positively influenced. Waldkirch \& Ofosu (2010) hires manufacturing firm data panels in Ghana. They note that the foreign existence in a sector has a substantial negative impact on domestic companies, but a positive influence on plants operated byforeigners. Turning to studies covering countries in Latin America, the picture is close-that is, the findings are mixed.

\section{RESEARCH METHODOLOGY}

Research methodology can be divided into quantitative and qualitative. Quantitative study involves systematic empirical research by statistical, mathematical or computational techniques into observable phenomena. The aim of quantitative research is to create and apply mathematical models, theories and hypotheses relating to study problem. The measurement process is integral to quantitative research since it offers a valuable link between empirical observation and the mathematical methods of linear association. Quantitative data is any data in form of numbers, like statistics, percentages, etc. 
The population is focused on Manufacturing firms in Oman. A total number of 410 respondents were selected randomly for this study from 9 categories of industry namely Textile, Petroleum products, Technology, Automobile, Food \& Beverages, Agriculture \& Fishery, Printing, Chemicals and Pharmaceuticals. In this research work, the research questionnaire was used as instrument for data collection and purposive sampling was used. This is a nonprobability sampling technique where subjects are purposely selected based on the choice of the researcher and simple random sampling technique.

Data analysis was done after the data gathered are coded and managed using the Statistical Package for Social Sciences (SPSS). The descriptive statistics which involves simple percentages, frequencies, bars and pie charts were used for analyzing demographic variables. While research questions and hypotheses were performed using Multiple Regression Analysis.

\section{DATA ANALYSIS AND INTERPRETATION}

This section is on data analysis and interpretation of findings. This study examines the relationship between Foreign Direct Investment (FDI) and performance of manufacturing industry in the Sultanate of Oman.

\subsection{DEMOGRAPHIC CHARACTERISTIC OF RESPONDENTS}

Table 1: Industry Category

\begin{tabular}{|c|c|c|}
\hline Industry Category & Frequency & Percent \\
\hline Textile & 67 & 16.3 \\
\hline Petroleum Products & 102 & 24.9 \\
\hline Technology & 90 & 22.0 \\
\hline Automobile & 25 & 6.1 \\
\hline Food \& Beverages & 15 & 3.7 \\
\hline Agriculture \& Fishery & 33 & 8.0 \\
\hline Printing & 20 & 4.9 \\
\hline Chemicals & 20 & 4.9 \\
\hline Pharmaceuticals & 38 & 9.3 \\
\hline Total & 410 & 100.0 \\
\hline
\end{tabular}

Table 1 shows that $102(24.9 \%)$ of the respondents were from Petroleum products industry, $90(22.0 \%)$ were from Technology sector, 67 (16.3\%) were from Textile industry, 38 (9.3\%) were from Pharmaceuticals industry, 33 (8.0\%) were from Agriculture \& Fishery industry, 25 (6.1\%) were from Automobile industry, 20 (4.9\%) were from Printing and Chemicals industry respectively while 15 (3.7\%) were from Automobile industry.

Table 2: Demography of Respondents

\begin{tabular}{|c|c|c|}
\hline Gender & Frequency & Percent \\
\hline Male & 261 & 63.7 \\
\hline Female & 149 & 36.3 \\
\hline Total & 410 & 100.0 \\
\hline Age (Years) & & \\
\hline 18-25 year & 134 & 32.7 \\
\hline $26-35$ years & 215 & 52.4 \\
\hline $36-45$ years & 49 & 12.0 \\
\hline 46-55 years & 6 & 1.5 \\
\hline Above 55 years & 6 & 1.5 \\
\hline Total & 410 & 100.0 \\
\hline Educational Qualification & & \\
\hline High School & 129 & 31.5 \\
\hline Diploma & 163 & 39.8 \\
\hline
\end{tabular}


A Study of Foreign Direct Investment on Manufacturing Industries in Sultanate of Oman

\begin{tabular}{|c|c|c|}
\hline Degree & 109 & 26.6 \\
\hline Postgraduate & 9 & 2.2 \\
\hline Total & 410 & 100.0 \\
\hline
\end{tabular}

Table 2 shows that $261(63.7 \%)$ of the respondents are male while 149 (36.3\%) are women. This implies that more men were involved in this study than women. Also, 215 (52.4\%) of the respondents are within the age group of 26-35 years, 134 (32.7\%) of the respondents are within the age group of 26-35 years, $49(12.0 \%)$ are within the age group of 36-45 years while $6(1.5 \%)$ are within the age groups of 46-55 years and more than 55 years respectively. This implies that majority of the respondents are within 26-35 years. Based on the educational qualification of respondents, 163 (39.8\%) of the respondents have Diploma, 129 (31.5\%) are High school graduates, 109 (26.6\%) have Bachelors degree while 9 (2.2\%) have Postgraduate degree.

\section{Hypothesis One}

$\mathrm{H}_{01}$ : There is no significant relationship between spillover of foreign direct Investment and growth of domestic firms in Oman

\begin{tabular}{|c|c|c|c|c|}
\hline \multicolumn{4}{|c|}{ Table : Model Summary } \\
\hline Model & R & R Square & Adjusted R Square & Std. Error of the Estimate \\
\hline 1 & $.296^{\mathrm{a}}$ & 0.088 & 0.067 & 2.32 \\
\hline
\end{tabular}

a. Predictors: (Constant), Skill Spillovers, Capital Spillover, Management Spillover, Efficiency Spillover, Direct Backward Linkages, Indirect Linkages, Marketing Spillover, Direct Forward Linkages, Technology Spillover

Table 4.9: ANOVA

\begin{tabular}{|c|c|c|c|c|c|c|}
\hline \multicolumn{2}{|c|}{ Model } & Sum of Squares & df & Mean Square & F & Sig. \\
\hline \multirow{4}{*}{1} & Regression & 206.732 & 9 & 22.97 & 4.266 & $.000 \mathrm{~b}$ \\
\cline { 2 - 7 } & Residual & 2153.86 & 400 & 5.385 & & \\
\cline { 2 - 7 } & Total & 2360.59 & 409 & & & \\
\hline
\end{tabular}

a. Dependent Variable: Growth of Domestic Firms

b. Predictors: (Constant), Skill Spillovers, Capital Spillover, Management Spillover, Efficiency Spillover, Direct Backward Linkages, Indirect Linkages, Marketing Spillover, Direct Forward Linkages, Technology Spillover

Table 4.10: Coefficients

\begin{tabular}{|c|c|c|c|c|c|}
\hline \multirow{2}{*}{ Model } & \multicolumn{2}{|c|}{ Unstandardized Coefficients } & Standardized Coefficients & \multirow{2}{*}{ Sig. } \\
\cline { 2 - 5 } & $\mathrm{B}$ & Std. Error & Beta & & \\
\hline (Constant) & 6.062 & 0.731 & & 8.293 & 0.000 \\
\hline Direct Backward Linkages & -0.471 & 0.214 & -0.125 & -2.201 & 0.028 \\
\hline Technology Spillover & -0.368 & 0.353 & -0.106 & -1.044 & 0.297 \\
\hline Marketing Spillover & -0.19 & 0.171 & -0.062 & -1.115 & 0.266 \\
\hline Management Spillover & -0.513 & 0.175 & -0.153 & -2.937 & 0.004 \\
\hline Efficiency Spillover & -0.142 & 0.085 & -0.089 & -1.667 & 0.096 \\
\hline Capital Spillover & 1.048 & 0.401 & 0.27 & 2.615 & 0.009 \\
\hline Indirect Linkages & 0.166 & 0.102 & 0.09 & 1.632 & 0.104 \\
\hline Direct Forward Linkages & 0.054 & 0.174 & 0.023 & 0.309 & 0.757 \\
\hline Skill Spillovers & -0.401 & 0.181 & -0.155 & -2.211 & 0.028 \\
\hline
\end{tabular}

a. Dependent Variable: Growth of Domestic Firms

The multiple regression model shows that spillover channels of FDI (Skill Spillovers, Capital Spillover, Management Spillover, Efficiency Spillover, Direct Backward Linkages, Indirect Linkages, Marketing Spillover, Direct Forward Linkages and Technology Spillover) significantly jointly influenced the growth of domestic firms $\left[\left(\mathrm{R}^{2}=.09\right.\right.$.; $\mathrm{F}(9,409)=4.266 ; \mathrm{p}<.00)]$. This infers that Skill Spillovers, Capital Spillover, Management Spillover, Efficiency 
Spillover, Direct Backward Linkages, Indirect Linkages, Marketing Spillover, Direct Forward Linkages and Technology Spillover jointly accounted for about 9.0\% of the variance observable in growth of domestic firms. Further, the independent contribution of Skill Spillovers, Direct Backward Linkages, Management Spillover, Efficiency Spillover and Capital Spillover were significant $[(\beta=-0.155 ; \mathrm{t}=-2.211 ; \mathrm{p}<.000),(\beta=-0.125 ; \mathrm{t}=-2.201 ; \mathrm{p}<$ $.000),(\beta=-0.153 ; \mathrm{t}=-2.937 ; \mathrm{p}<.000),(\beta=-0.089 ; \mathrm{t}=-1.667 ; \mathrm{p}<.000)$ and $(\beta=0.27 ; \mathrm{t}=2.615 ; \mathrm{p}<.000)$. Capital Spillover was positively significant while Skill Spillovers, Direct Backward Linkages, Management Spillover, Efficiency Spillover were negatively significant. Also, Technology Spillover, Marketing Spillover, Indirect Linkages and Direct Forward Linkages were not statistically significant.

\section{Hypothesis Two}

$\mathrm{H}_{02}$ : There is no significant impact of spillover of foreign direct Investment on the economy of Oman

Table 4.11: Model Summary

\begin{tabular}{|c|c|c|c|c|}
\hline Model & $\mathrm{R}$ & R Square & Adjusted R Square & Std. Error of the Estimate \\
\hline 1 & $.822^{\mathrm{a}}$ & 0.676 & 0.559 & 3898.47 \\
\hline
\end{tabular}

a. Predictors: (Constant), Skill Spillovers, Capital Spillover, Management Spillover, Efficiency Spillover, Direct Backward Linkages, Indirect Linkages, Marketing Spillover, Direct Forward Linkages, Technology Spillover

Table 4.12: ANOVA

\begin{tabular}{|c|c|c|c|c|c|c|}
\hline \multicolumn{2}{|c|}{ Model } & Sum of Squares & df & Mean Square & F & Sig. \\
\hline & Regression & 791408610 & 9 & 87934290 & 5.786 & $.000 \mathrm{~b}$ \\
\cline { 2 - 7 } & Residual & 379952088 & 25 & 15198083.5 & & \\
\hline Total & 1171360698 & 34 & & & \\
\hline
\end{tabular}

a. Dependent Variable: GDP

b. Predictors: (Constant), Skill Spillovers, Capital Spillover, Management Spillover, Efficiency Spillover, Direct Backward Linkages, Indirect Linkages, Marketing Spillover, Direct Forward Linkages, Technology Spillover

Table 4.13: Coefficients

\begin{tabular}{|c|c|c|c|c|c|}
\hline \multirow{2}{*}{ Model } & \multicolumn{2}{|c|}{ Unstandardized Coefficients } & Standardized Coefficients & \multirow{2}{*}{ Sig. } \\
\cline { 2 - 5 } & $\mathrm{B}$ & Std. Error & Beta & & \\
\hline (Constant) & 4049.301 & 4899.097 & & .827 & .416 \\
\hline Direct Backward Linkages & -2559.980 & 1631.247 & -.193 & -1.569 & .129 \\
\hline Technology Spillover & 1875.224 & 1982.458 & .304 & .946 & .353 \\
\hline Marketing Spillover & 788.740 & 924.811 & .113 & .853 & .402 \\
\hline Management Spillover & -74.465 & 1475.869 & -.006 & -.050 & .960 \\
\hline Efficiency Spillover & -2866.325 & 1512.218 & -.243 & -1.895 & .070 \\
\hline Capital Spillover & 164.425 & 1750.422 & .029 & .094 & .926 \\
\hline Indirect Linkages & 3661.554 & 1705.739 & .310 & 2.147 & .042 \\
\hline Direct Forward Linkages & 3075.770 & 1247.405 & .447 & 2.466 & .021 \\
\hline Skill Spillovers & -435.552 & 1557.426 & -.048 & -.280 & .782 \\
\hline
\end{tabular}

a. Dependent Variable: GDP

The multiple regression model shows that spillover channels of FDI (Skill Spillovers, Capital Spillover, Management Spillover, Efficiency Spillover, Direct Backward Linkages, Indirect Linkages, Marketing Spillover, Direct Forward Linkages and Technology Spillover) significantly jointly influenced the GDP (economy of Oman) [(R2 = .68.; $\mathrm{F}(9,34)=5.786 ; \mathrm{p}<.00)]$. This infers that Skill Spillovers, Capital Spillover, Management Spillover, Efficiency Spillover, Direct Backward Linkages, Indirect Linkages, Marketing Spillover, Direct Forward Linkages and Technology Spillover jointly accounted for about $68.0 \%$ of the variance observable in growth of economy of Oman. Further, the independent contribution of Indirect Linkages and Direct Forward Linkages were both positively significant $[(\beta=.310 ; \mathrm{t}=2.147 ; \mathrm{p}<.000)$ and $(\beta=0.447 ; \mathrm{t}=2.466 ; \mathrm{p}<.000)$ while Capital Spillover, Skill Spillovers, 
A Study of Foreign Direct Investment on Manufacturing Industries in Sultanate of Oman

Direct Backward Linkages, Management Spillover, Efficiency Spillover, Technology Spillover, and Marketing Spillover were not statistically significant.

\section{SUMMARY AND CONCLUSION}

The results of this study also revealed that the spillover impacts on domestic companies, like novel technology, marketing strategies, organizational skills, money, jobs, export growth, diversifying of economy and greater competition, lead to enhanced domestic market efficiency and boosted productivity in skill-spreading host economies with the highest impact accompanied with Capital and Technology spillover.

In hypothesis one, FDI's spillover networks (Skill Spillovers, Capital Spillover, Management Spillover, Capacity Spillover, Direct Backward Linkages, Indirect Linkages, Advertising Spillover, Direct Forward Linkages and Spillover Technology) greatly affected dvelopment of domestic firms together. In addition, the independent contribution of Ability Spillovers, Direct Backward Linkages, Management Spillover, Efficiency Spillover and Technology Spillover was significant as Technology Spillover was positive and Ability Spillovers, Direct Backward Ties, Management Spillover, Efficiency Spillover were negative while Capital Spillover, Marketing spillover, Indirect Linkages and Direct Forward Linkages were negative.

In hypothesis two, FDI's spillover networks (Skill Spillovers, Capital Spillover, Administration Spillover, Capacity Spillover, Direct Backward Linkages, Indirect Linkages, Advertising Spillover, Direct Forward Linkages, and Technology Spillover) affected the GDP (Oman's economy) substantially together. However, the independent contribution of Indirect Linkages and Direct Forward Linkages was both positive. However, Capital Spillover, Knowledge Spillovers, Direct Backward Linkages, Management Spillover, Capacity Spillover, Technology Spillover, and Marketing Spillover were not significant.

For most industries, Oman approved $100 \%$ foreign direct investment ownership of companies; allowed international, non-GCC, businesses to acquire properties and rent land. At the downside, in respect to privatization, GCC nations still fall behind other Middle East nations.

Actually, Oman is one of several nations suffering from a low-savings propensity resulting into minimal domestic investment. Such circumstances call for a rise in savings and thus enhance rate of investments like international investment, to cover the savings-investment challenges. In the industrial segment, FDI stand for only 30 percent of overall foreign investment; other investment and international portfolio investment constitute the other 70 percent, whereas within the oil and gas segment, FDI contributes 51 percent, while other investment and international portfolio constitute the other 49 percent.

FDI's influence on the economy had been strongly skewed in the direction of oil sector, such that FDI performs a marginal role and contributing a minority to non-oil development, exportation and job development. If FDI is to contribute significantly to the creation of employment opportunities for citizens of the Sultanate, it is necessary to develop industries like commerce, transportation, ICT; property investment, healthcare, agriculture and education, in which many of citizens of Oman in the private sector work.

\section{Conclusion}

The outcome of this research indicated that spillover networks of FDI positively affect the development of local companies with the highest magnitude of capital spillover accompanied by Skill spillovers and Direct Backward Linkages. The spillover outlets of FDI also had a significant impact on GDP (Oman's economy). The study reported that Oman had some positive FDI spillover impacts.

The private sector is supplying economic development with energy and potential. There is less rivalry in this industry and assistance from government in terms of funding and subsidy input. Domestic request for products and services is lower, because Oman depends largely on importation. Conversely, this industry is segmented into smaller groups so it can not remain competitive with foreign companies and thus has an ineffective potential to advance and stimulate more knowledge from surviving FDI companies. Oman has certain aspects that could end up making Oman a much less fascinating investment options for some industries. 


\section{RECOMMENDATIONS}

The recommendations for this study are as follows:

1) In order to fascinate FDI and use it to increase spillover profitability, it helps to offer what investors are searching for. That could be divided into two groups. The first involves business requirements based on economies of scale, cheaper inputs (labour, resources, and energy), relationship between Oman and other nations in the world and authentic opportunities with huge profitability.

2) Secondly, involves the political danger that most matters for MNCs operations and is closely correlated with FDI inflows. That affects the steadiness of governments, interior and exterior divergence, fraud, accountability and precision.

3) Policymakers in Oman should enact policies that would safeguard foreign investments and seek to follow a policy that would ensure a stable government.

\section{SOURCES OF FUNDING}

The research leading to these results has received funding from the Research Council (TRC) of the Sultanate of Oman under the Block Funding Program. TRC Block Funding Agreement No: BFP/RGP/EHR/18/123.

\section{CONFLICT OF INTEREST}

The author have declared that no competing interests exist.

\section{ACKNOWLEDGMENT}

On behalf of the TRC funded project team, I would like to thanks to;

1) The Research Council (TRC) of the Sultanate of Oman.

2) Mazoon College, Muscat, Sultanate of Oman.

3) The Research Center, Mazoon College.

\section{REFERENCES}

[1] Aitken, B. and Harrison, A. (1999). "Do domestic firms benefit from direct foreign investment? Evidence from Venezuela”, American Economic Review, 89(x): 605-618.

[2] Farole, T. and Winkler, D. (2013) Making foreign direct investment work for Sub-Saharan Africa: local spillovers and competitiveness in global value chains. Directions in Development: Trade. Washington DC: World Bank Group

[3] Fu, X., Zanello, G. Essegbey, G. Hou, J. and Mohnen, P. (2014),'Innovation in low income countries: a survey report'. Oxford: TMDC

[4] Girma, S., Görg, H. \& Pisu, M. (2008) Exporting, linkages and productivity spillovers from foreign direct investment. Can J Econ 41:320-340

[5] Hill, C.W.L. (2005). International Business: competing in a global market place, (5th ed.), Boston: McGraw-Hill Publishers.

[6] Kravtsova V, Zelenyuk V (2007) Foreign knowledge, what does it bring to domestic firms? Malmquist productivity index in test for FDI spillovers. Working Paper of UNU-MERIT

[7] Kumar A. (2007). Foreign direct investment; Insights from the Federal Reserve Bank of Dallas; Vol. 2 No 1.

[8] Lin P, Liu Z, Zhang Y (2009) Do Chinese domestic firms benefit from FDI inflow? Evidence of horizontal and vertical spillovers. China Econ Rev 20:677-691

[9] Mwilima, N. (2003). Foreign direct investment in Africa. Social Observatory Pilot Project, Final Draft Report for the Labour Resource and Research Institute, 29-45 